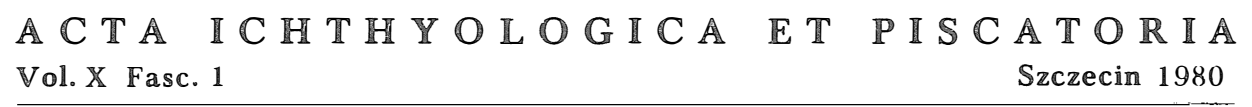

Jerzy SZYPUEA

Fish Biology

\title{
ASSESSMENT OF THE EFFECT OF ENVIRONMENTAL FACTORS ON FISH GROWTH USING GROWTH COEFFICIENTS CALCULATED FROM MATHEMATICAL DESCRIPTION OF FISH GROWTH BY MEANS OF POLYNOMIALS
}

\author{
ORREŚLANIE WPEYWU CZYNNIKÓW SRODOWISKOWYCH NA WZROST RYB \\ PRZY POMOCY WSPÓECZYNNIKA WZROSTU, OBLICZANEGO \\ NA PODSTAWIE MATEMATYCZNEJ CHARARTERYSTYKII WZROSTU RYB \\ PRZY UZZYCIU FUNKCII WIELOMIANOWYCH
}

\author{
Institute of Ichthyology, Szczecin
}

\begin{abstract}
The paper describes a method for a mathematical characterisation of fish growth with the use of non-asymptotic growth models (bi- and trinomials). The method allows to obtain results equally accurate as when von Bertalanffy's equation is used; additionally, a new version of growth coefficient is possible to calculate. The coefficient can be applied to a precise determination of effects of various environmental factors on fish growth. If the relationship between the growth coefficient and a given factor's effect is presented as a linear correlation, the regression equation slope coefficient may be taken as representing the intensity of the factor's effect on growth.
\end{abstract}

\section{INTRODUCTION}

In recent studies on fish growth there has been a tendency to a simultaneous assessment of growth of several main species co-occurring in a given habitat. This 
tendency is undoubtedly justified since the co-occurring species affect one another's basic life processes, including growth.

Such a simultaneous description of growth of several fish species (or comparisons of growth of several conspecific populations inhabiting environments of differing characteristics) poses the necessity of applying a uniform methodology to compare the growth of several species or of various conspecific populations. The present work was aimed at finding a method which would enable an unequivocal and accurate comparison of growth of various fish species as well as at determining the effect of environmental factors such a temperature salinity, latitude etc. on growth rate.

A good criterion with which to compare accurately the growth of various species is the surface area contained between the growth curve and the x-axis (time axis). Given a mathematical presentation of a species' growth as a function of time, the area can be calculated by integrating the function. However, a problem arises as to which time moment should be assumed as a limit to fish growth (the upper limit of the integral). Therefore, either a growth-limiting age common to all the species concerned should be arbitrarily chosen (which is, however, impossible owing to the growth proceeding in a very diversified manner in each species), or such a limit should be established for each species separately, which in turn gives rise to a new question: what criteria of fixing this growth limit should be chosen to render various species or populations fully comparable.

The solution to this problem is to express fish lengths and weights by means of non-asymptotic functions reaching their maxima over a strictly determined time interval considered a theretical growth limit. Polynomials appear to be relatively simple functions for which it is easy to calculate the time they reach their maxima in; taking into consideration the shape of typical fish growth curves, the length growth may be expressed by a binomial and weight growth by a trinomial.

Symbols and abbreviations used throuhout this paper are:

$\mathrm{L} \quad=$ length $(\mathrm{cm})$;

$\mathrm{W} \quad=$ weight $(\mathrm{g})$;

$\mathrm{t} \quad=$ time (years);

$t_{\max }=$ theoretical maximum age (growth time);

$\mathrm{t}_{\min }=$ teoretical age at which the weight growth function reaches its minimum;

$\mathrm{L}_{\max }=$ theoretical maximum length (corresponding to the age $\mathrm{t}_{\max }$ );

$\mathrm{W}_{\max }=$ theoretical maximum weight (corresponding to the age $\mathrm{t}_{\max }$ );

$\mathrm{t}_{\mathrm{p}}=$ age at which the theoretical weight growth proceeds uniformly (point of inflection of the weight growth function);

$\mathrm{V}_{\mathrm{L}} \quad=$ length growth rate;

$\overline{\mathrm{V}}_{\mathrm{L}}=$ mean length growth rate;

$\mathrm{V}_{\mathrm{W}} \quad$ = weight growth rate;

$\overline{\mathrm{V}}_{\mathrm{W}} \quad=$ mean weight growth rate;

$\mathrm{C}_{\mathrm{L}} \quad=$ coefficient of changes in length growth rate;

$\mathrm{C}_{\mathrm{W}} \quad=$ coefficient of changes in weight growth rate;

$\mathrm{G}_{\mathrm{L}} \quad$ = length growth coefficient; 
$\mathrm{G}_{\mathrm{W}} \quad=$ weight growth coefficient;

$\mathrm{G}_{(\mathrm{L})} \quad=$ relative length growth coefficient;

$\mathrm{G}_{(\mathrm{W})} \quad$ = relative weight growth coefficient;

$\mathrm{R}_{\mathrm{L}} \quad$ = range of length growth fluctuations;

$\mathbb{R}_{\mathrm{W}} \quad=$ range of weight growth fluctuations.

\section{MATERIAL AND METHODS}

Results of studies by various authors on growth of different fish species were used as a material for developing a method for expressing the length and weight growth in terms of bi- and trinomials. With respect to length, the results had been most frequently back-calculated, a part of them being, however, calculated directly from length measurements. Data on weight growth had been obtained from either direct weighings or length-weight relationships.

As stated above, a binomial

$$
\text { or } \begin{aligned}
y & =a+b x+c x^{2} \\
L_{t} & =a+b t+c t^{2}
\end{aligned}
$$

was used to describe the length growth. The binomial parameters $(a, b$, and $c)$ were each time calculated by the least squares method. A graphical presentation of the fish length growth as determined by the binomial is given in Fig. 1 .

As oooised to the growth models proposed by von Bertalanffy (Beverton and Holt, 1957), Gompertz (Cięglewicz and Draganik, 1969), and Ford and Walford (Rounsefell and Everhart, 1953), which assume an asymptotic growth of body length and weight, a biomial modeling of lenght and weight assumes a complete cessation of theoretical growth at a precisely fixed time $t_{\max }$. The latter can be calculated by differentiating the growth equation with respect to $t$ and equaling the derivative obtained to 0 . In case of the length growth, $\mathrm{t}_{\max }$ is calculated as follows:

thus

$$
\frac{\mathrm{dL}}{\mathrm{dt}}=\mathrm{b}+2 \mathrm{ct}=0
$$

$$
\mathrm{t}_{\max }=-\frac{\mathrm{b}}{2 \mathrm{c}}
$$

Substituting the obtained $t_{\max }$ to the length growth equation, a theoretical maximum length for the species (population) can be calculated:

$$
L_{\text {max }}=a+b\left(-\frac{b}{2 c}\right)+c\left(-\frac{b}{2 c}\right)^{2}=a-\frac{b^{2}}{4 c}
$$

The length growth rate $\left(\mathrm{V}_{\mathrm{L}}\right)$ can be calculated by differentiating the length growth equation with respect to $t$ : 


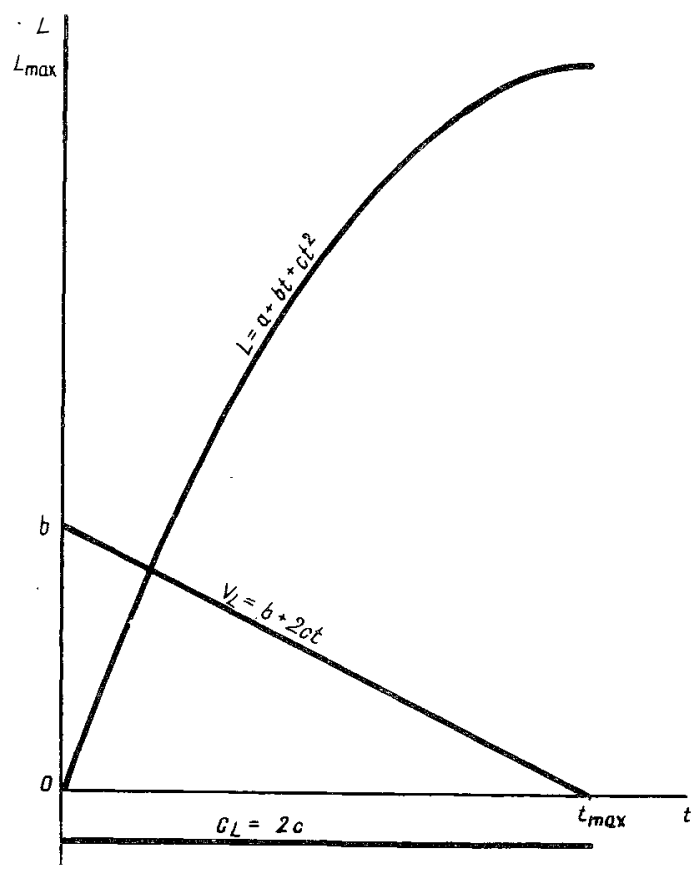

Fig. 1. Fish length growth described with a binomial

$$
\mathrm{V}_{\mathrm{L}}=\frac{\mathrm{d} \mathrm{L}}{\mathrm{dt}}=\mathrm{b}+2 \mathrm{ct}
$$

The length growth rate average for the whole theoretical grwoth period can be calculated by dividing the $\mathrm{L}_{\max }$ obtained previously by $\mathrm{t}_{\max }$ :

$$
\overline{\mathrm{V}}_{\mathrm{L}}=\frac{\mathrm{L}_{\text {max }}}{\mathrm{t}_{\text {max }}}
$$

The value of change in the length growth rate $\left(C_{L}\right)$ can be determined as the second derivative of the length growth equation:

$$
C_{L}=\frac{d^{2} L}{{d t^{2}}^{2}}=2 c
$$

As seen from above, the value remains constant and equal to the doubled value of $\mathrm{c}$. Since $c$ is always negative in the length growth equation, $C_{L}$ becomes negative as well, which should be interpreted so that length increments decrease with time by a constant value equal to $C_{L}$. Fig. 1 presents changes in $V_{L}$ and $C_{L}$ over time.

As stated above, the area enclosed by the growth curve, $\mathrm{x}$-axis (time axis), and a line perpendicular to it and intersecting it at $t_{\max }$ is assumed to be the comparative criterion. 
Knowing the growth curve equation, the area can be calculated by integrating the latter. If the length growth is described by the binomial, the area in question, in other words a coefficient of length growth $\left(G_{L}\right)$ is expressed as

$$
G_{\mathrm{L}}=\int_{0}^{t_{\mathrm{max}}}\left(a+b t+c t^{2}\right) d t=a t_{\text {max }}+\frac{b t_{\text {max }}{ }^{2}}{2}+\frac{c t_{\text {max }}{ }^{3}}{3}
$$

The coefficient of lenght growth calculated in this way is also applicable to the determination of growth range in a given species (population). When, apart from mean lengths typical of the consecutive years of life of individuals from a given population, a variability coefficient (v) as a dispersion measure, and then its mean value ( $\bar{v})$ for the life span are calculated, the length growth can be presented with three curves: the first, calculated from mean lengths $(\mathbb{L})$; the second, calculated from mean lengths enlarged by the mean variability coefficient $(\mathbb{L}+\bar{v})$; and the third, calculated from mean lengths by the mean variability coefficient $(\mathrm{L}-\overline{\mathrm{v}})$. This procedure of determining the length growth is presented in Fig. 2. The difference between the second and the third curve (a hatched area in Fis. 2) can be regarded as a measure of grwoth fluctuations. Their range can be calculated by determining the difference between growth coefficients computed from curve equations. To arrive at values comparable for different fish species, the range of lenght growth fluctuations $\left(R_{L}\right)$ should be expressed in per cent with respect to the growth coefficient calculated from mean lengths:

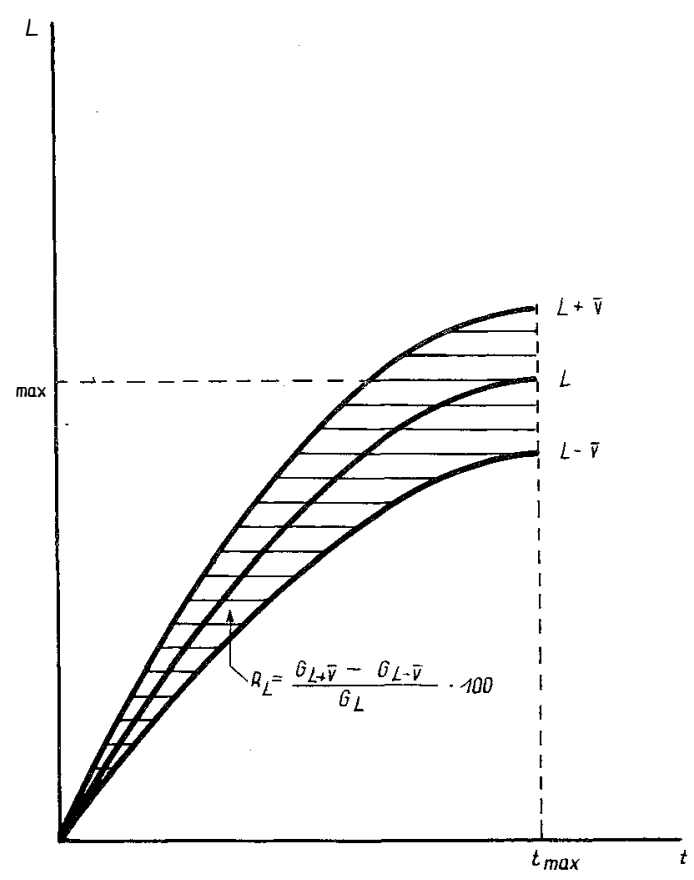

Fig. 2. Range of length growth in fishes 


$$
R_{L}=\frac{G_{(L+\bar{v})}-G_{(L-\bar{v})}}{G_{L}} \cdot 100
$$

The weight growth is described by a trinomial

or

$$
\begin{aligned}
y & =a+b x+c x^{2}+d x^{3} \\
W_{t} & =a+b t+c t^{2}+d t^{3}
\end{aligned}
$$

The parameters of this polynomial can be determined, similarly to the binomial, by means of the least aquares method. A graphical representation of the fish weight growth as expressed by the trinomial is given in Fig. 3 .

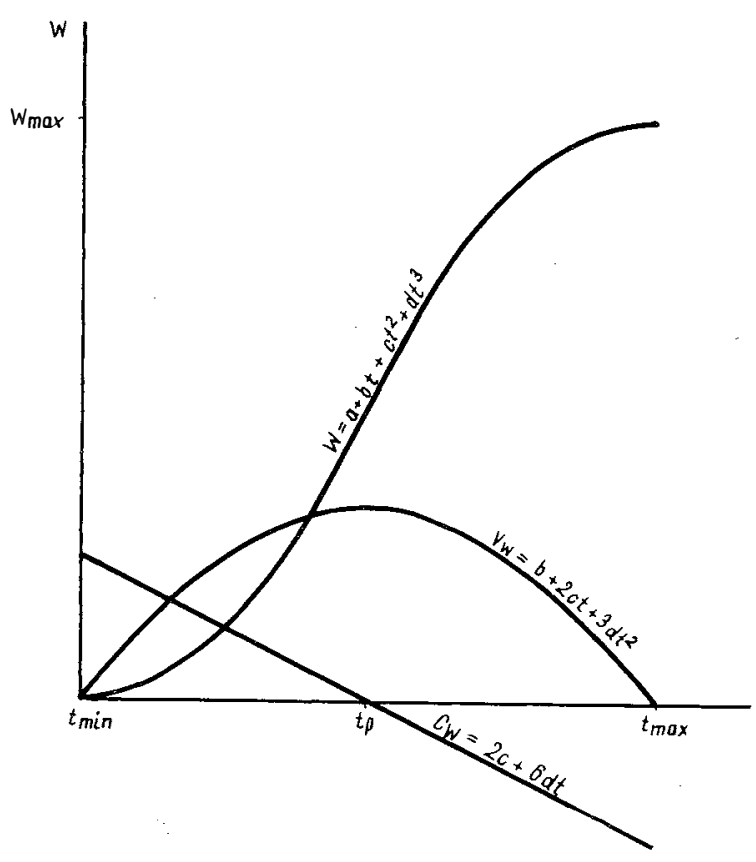

Fig. 3. Fish weight growth described with a trinomial

A typical fish weight growth curve is well-known to take an S-shape when presented on a graph; this means that the weight growth rate is observed to increase in the first stage of fish life and to decrease gradually later on. Since the empirical data on weight growth covered in most species the period of increasing rate only, the following procedure was adopted when calculating the polynomial parameters: from the empirical data on lenght and weight growths of a species the length-weight relationship was calculated using the commonly accepted equation

$$
\mathrm{W}=\mathrm{k} \mathrm{L}^{\mathrm{n}}
$$


Then, after finding a length equation (a binomial) for theoretical lenhths calculated from this binomial, encompassing the entire period of theoretical growth (from $L_{1}$ to $L_{\max }$ ), weights were calculated from the previously found length-weight relationship. The respective weights for the consecutive years of life of individuals of a given species, calculated in this way, served as a material for finding the trinomial parameters.

The values of $t_{\max }, \mathrm{W}_{\max }, \mathrm{V}_{\mathrm{W}}, \overline{\mathrm{V}}_{\mathrm{W}}, \mathrm{C}_{\mathrm{W}}, \mathrm{G}_{\mathrm{W}}$, and $\mathrm{R}_{\mathrm{W}}$ were calculated identically as in case of the iength growth:

$$
\begin{aligned}
& \mathrm{t}_{\max }=\frac{-2 \mathrm{c}-\sqrt{\Delta}}{6 \mathrm{~d}} \text { where } \Delta=4 \mathrm{c}^{2}-12 \mathrm{db} \\
& W_{\max }=a-\frac{b c}{3 d}-\frac{b \sqrt{\Delta}}{6 d}+\frac{2 c^{3}}{27 d^{2}}+\frac{c^{2} \sqrt{\Delta}}{18 d^{2}}-\frac{\Delta \sqrt{\Delta}}{216 d^{2}} \\
& V_{W}=\frac{d W}{d t}=b+2 c t+3 d t^{2} \\
& \overline{\mathrm{V}}_{\mathrm{W}}=\frac{\mathrm{W}_{\max }}{\mathrm{t}_{\max }} \\
& C_{W}=\frac{d^{2} W}{{d t^{2}}^{2}}=2 c+6 d t \\
& \mathrm{G}_{\mathrm{W}}=\int_{0}^{\mathrm{t}_{\max }}\left(\mathrm{a}+\mathrm{bt}+\mathrm{ct}^{2}+d \mathrm{t}^{3}\right) \mathrm{dt}=\mathrm{at} \mathrm{max}_{\max }+\frac{\mathrm{bt}_{\mathrm{max}}^{2}}{2}+\frac{\mathrm{ct}_{\mathrm{max}}^{3}}{3}+\frac{\mathrm{dt}_{\max }^{4}}{4} \\
& R_{W}=\frac{G_{(W+\bar{v})}-G_{(W-\bar{v})}}{G_{W}} \cdot 100
\end{aligned}
$$

Two additional parameters may be calculated when using the trinomial for the weight growth description:

$$
\begin{aligned}
& t_{\text {min }}=\frac{-2 c+\sqrt{\Delta}}{6 d} \\
& t_{p}=-\frac{c}{3 d}
\end{aligned}
$$

$\mathrm{t}_{\text {min }}$ is a theoretical time in which the weight growth function falls down to its minimum, while $t_{p}$ is the point of inflection of the weight growth curve.

To supplement the length and weight growth characterstics, a coefficient, obtained from dividing the growth coefficient by the theoretical maximum age $\left(\mathrm{t}_{\max }\right)$ of the species and termed "a relative growth coefficient" was applied: 


$$
\begin{aligned}
& G_{(L)}=\frac{G_{L}}{t_{\max }} \\
& G_{(W)}=\frac{G_{W}}{t_{\max }}
\end{aligned}
$$

In order to test the applicability of the length growth coefficient in determining effects of various environmental conditions on fish growth, an attempt was made to describe such relationships by means of linear correlations; it war rather the sign of a correlation coefficient and not the value thereof that was considered important in each case. The correlations were calculated from data reported by various authors on length growth of 11 fish species; data on such factors relevant to the studied species' growth as temperature, salinity, population density etc. were also available. Since the interrelationships between growth of a species and various environmental factors as well as the presence of identical relationships for the species in various areas are frequently stressed in this paper, the total number of 40 interrelationships were worked out, each one being determined from 3-15 previously calculated values of the length growth coefficient and corresponding values characterising the effect of a relevant environmental factor.

\section{RESULTS}

The mathematical description of fish length and weight growth by means of bi- and trinomials allows results approaching the empirical data to be obtained. According to Szypuła (1977), polynomials used to determine fish growth yield results which are as accurate as those obtained when the von Bertalanffy's method is used. For example, Figs. 4 and 5 present the length and weight growth of perch from the Lake Ladoga (Collective Report, 1949) as determined by means of polynomials (curves) and compared with the empirical data (points). As can be observed, the curves representing the theoretical growth of length and weight of the species coincide almost completely with the empirical data, which proves a high accuracy of the results calculated using the procedure described in this paper.

The rationale behind the growth coefficients calculation procedure outlined in this paper is a possibility of determining effects of environmental factors on the course of fish growth. Many authors using a variety of methods tried to determine those effects (Burd, 1958; Taylor, 1958; May et al., 1964; Cięglewicz and Hoppe, 1970).

In the present paper, an attempt to use the length growth coefficient $\left(G_{L}\right)$ to characterise effects of various environmental factors on growth of different fish species was made. The weight growth coefficient $\left(\mathrm{G}_{\mathrm{W}}\right)$ would most likely serve this purpose equally well; the reports available, however, as a rule present length growth changes 


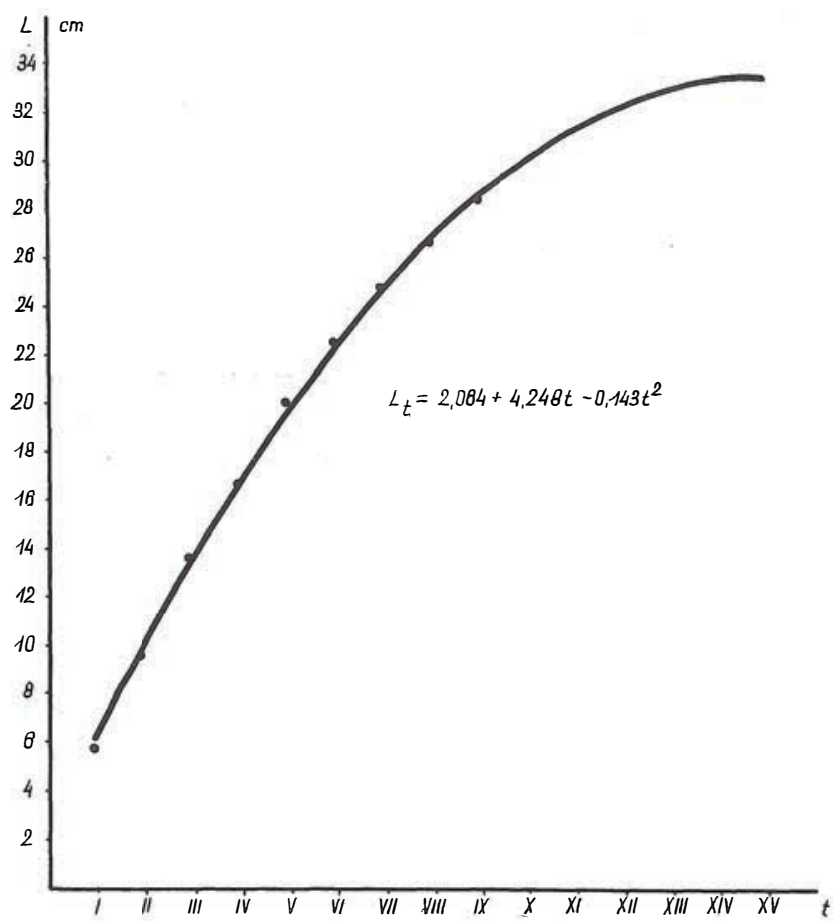

Fig. 4. Theoretical length growth of perch in the Lake Ladoga as described with a binomial (points denote lengths found empirically in consecutive years of life).

accompanying alterations in environmental factors and thus it was the length growth coefficient that was chosen for the present work.

Table 1 summarises 10 correlations between the length growth coefficient and northern latitude; the table contains values of the correlation coefficient and regression equations. All the coefficients were negative, which should be interpreted as a manifestation of a reversed correlation between the data studied. In other words, the length growth coefficient decreases with increasing latitude.

An absolute value of the slope coefficient in a regression equation (i.e., the value of $b$ in an equation such as $y=a+b x)$ describing a given relationship can be taken as a measure of the extent to which the factor studied affects the species (population) in question. To present the above statement numerically: the slope coefficient in case of the length growth coefficient-latitude relationship denotes an average change in the length growth coefficient with a $1^{\circ}$ shift in latitude.

Fig. 6 presents the relationship between cod length growth coefficient and latitude within the ICNAF area. The data on growth of cod from various ICNAF subareas, serving to calculate the length growth equation and coefficient were taken from May et al. (1964). A marked fecline in the cod length growth coefficient is observed to accompany the shift latitude from $44^{\circ} \mathrm{N}$ to $57^{\circ} \mathrm{N}$. 


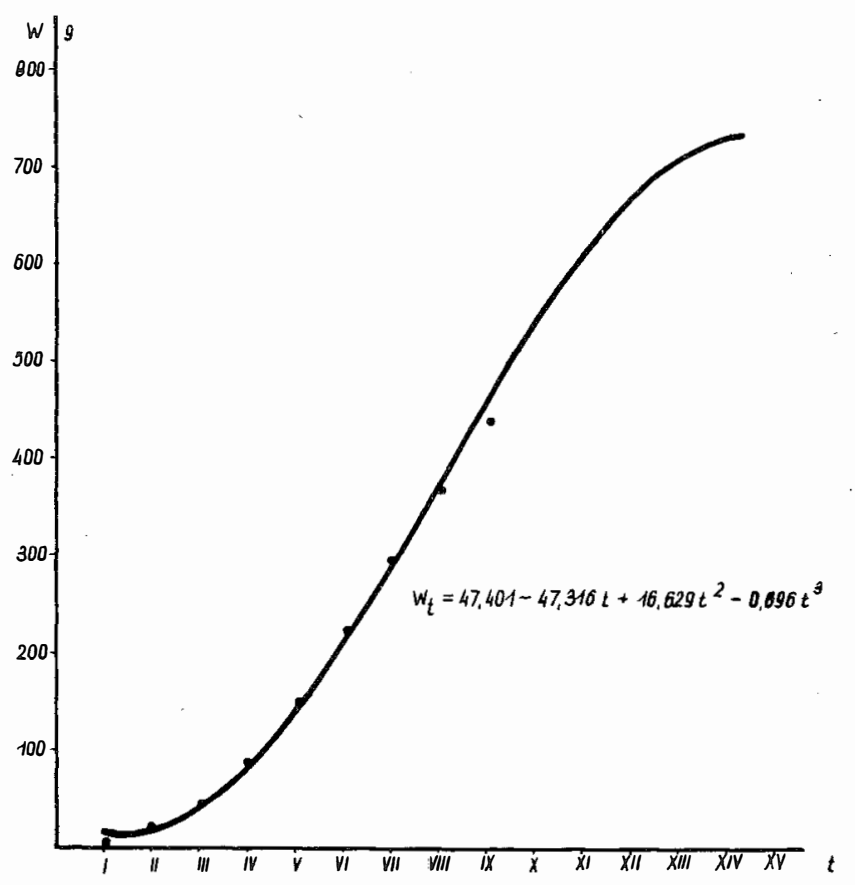

Fig. 5. Theoretical weight growth of perch in the Lake Ladoga as described with a trinomial

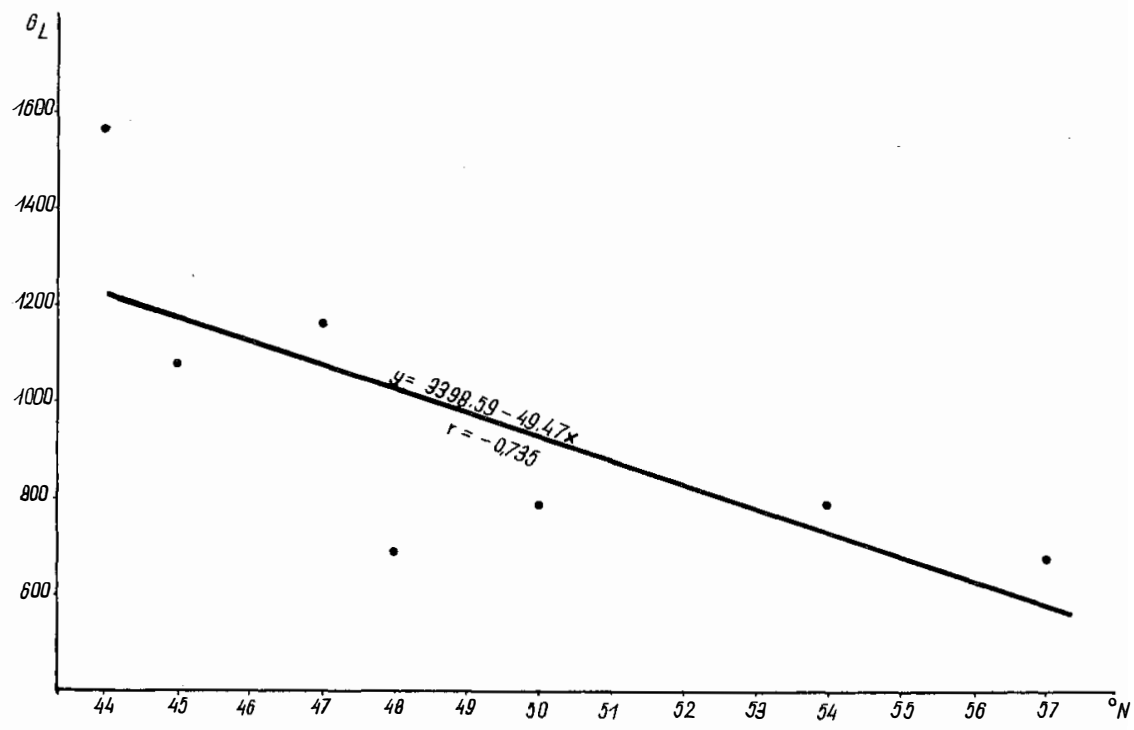

Fig. 6. Relationships between cod length growth coefficient and latitude in the ICNAF area 
Relationship between length coefficient $\left(G_{L}\right)$ and latitude $\left({ }^{\circ} \mathrm{N}\right)$ in various fish species

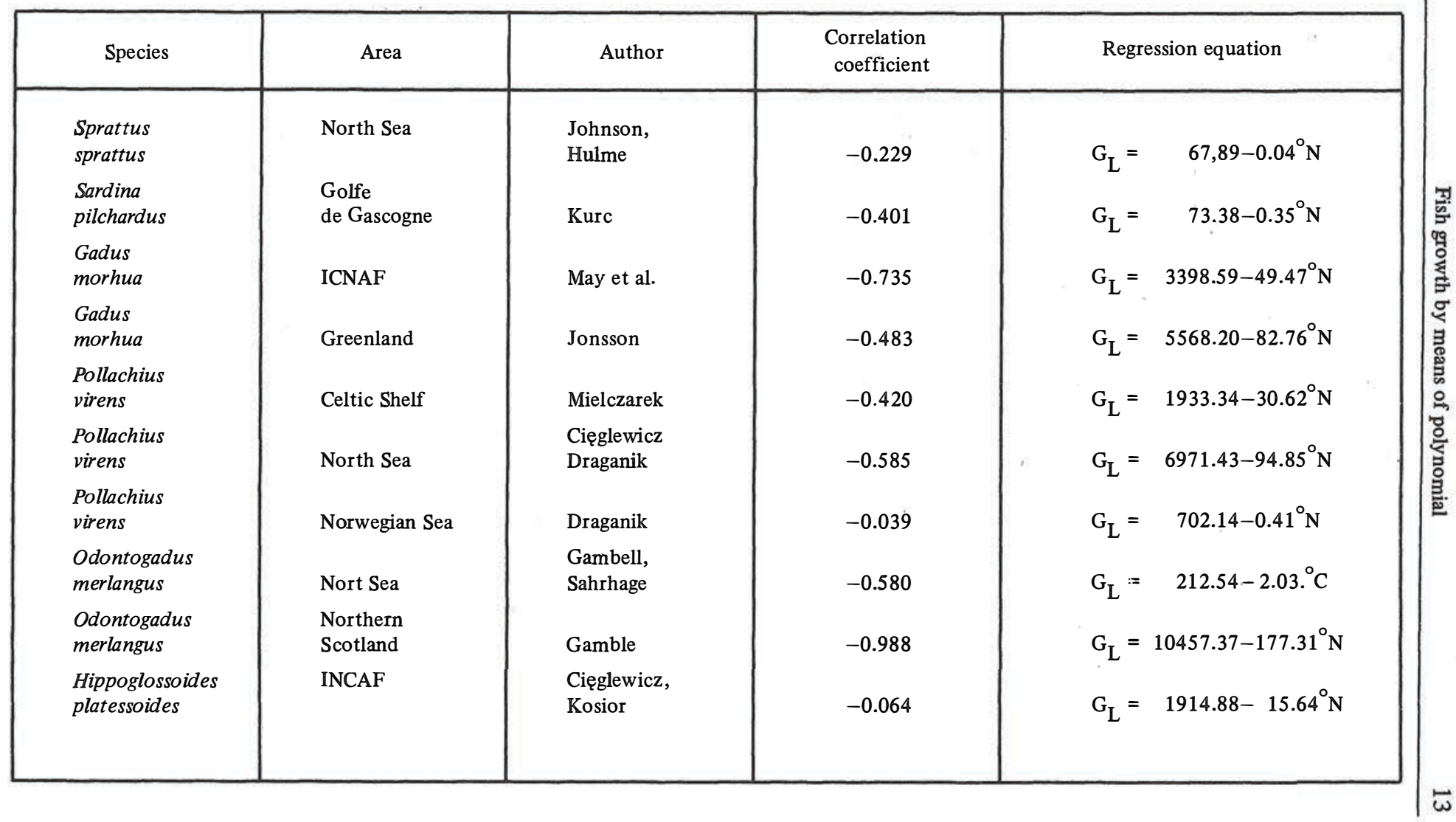


Table 2

Relationship between length growth coefficient $\left(G_{L}\right)$ and water temperature $\left({ }^{\circ} \mathrm{C}\right)$ in various fish species

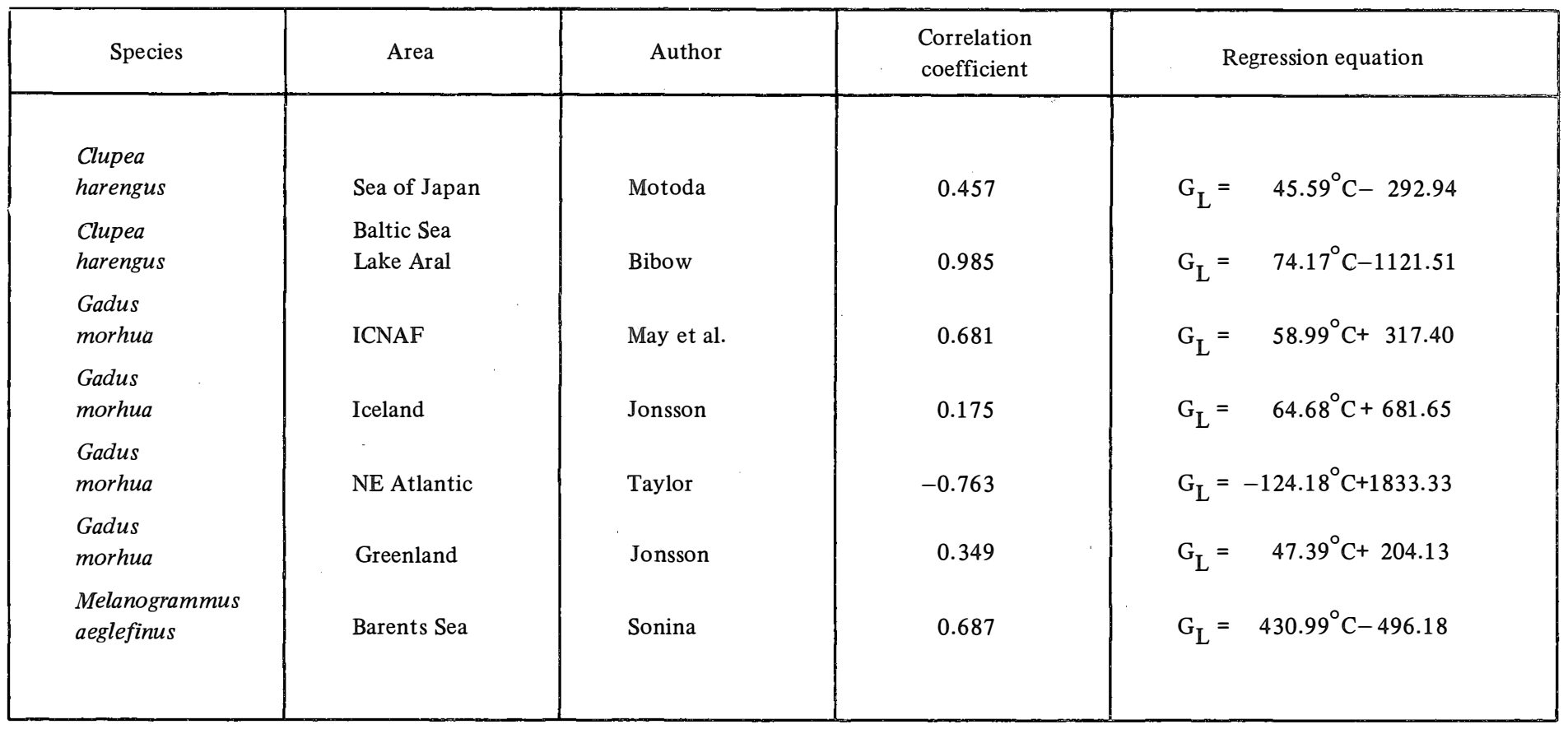


Table 2 summarises data on the length growth coefficient-water temperature relations ip. In 6 out of the 7 instances examined, positiąe correlation coefficients pointing to a direct relationship between water temperature and the length growth coefficient were obtained. However, the results calculated for the North-East Atlantic cod from data supplied by Taylor (1958) indicate to a reversed relationship between the indices studied (a relatively high negative correlation coefficient). In this case it was perhaps a simultaneous strong action of some other factor that exceeded the effect of temperature on the species growth. Fig. 7 presents the relationship between the ICNAF cod length growth coefficient (May et at., 1964) and water temperature ranging within $6-16^{\circ} \mathrm{C}$. As opposed to the previously described relationship, this is a direct one, the regression equation slope coefficient ((Table 2$)$ signifying an average change in the length growth coefficient accompanying a $1^{\circ} \mathrm{C}$ temperature change.

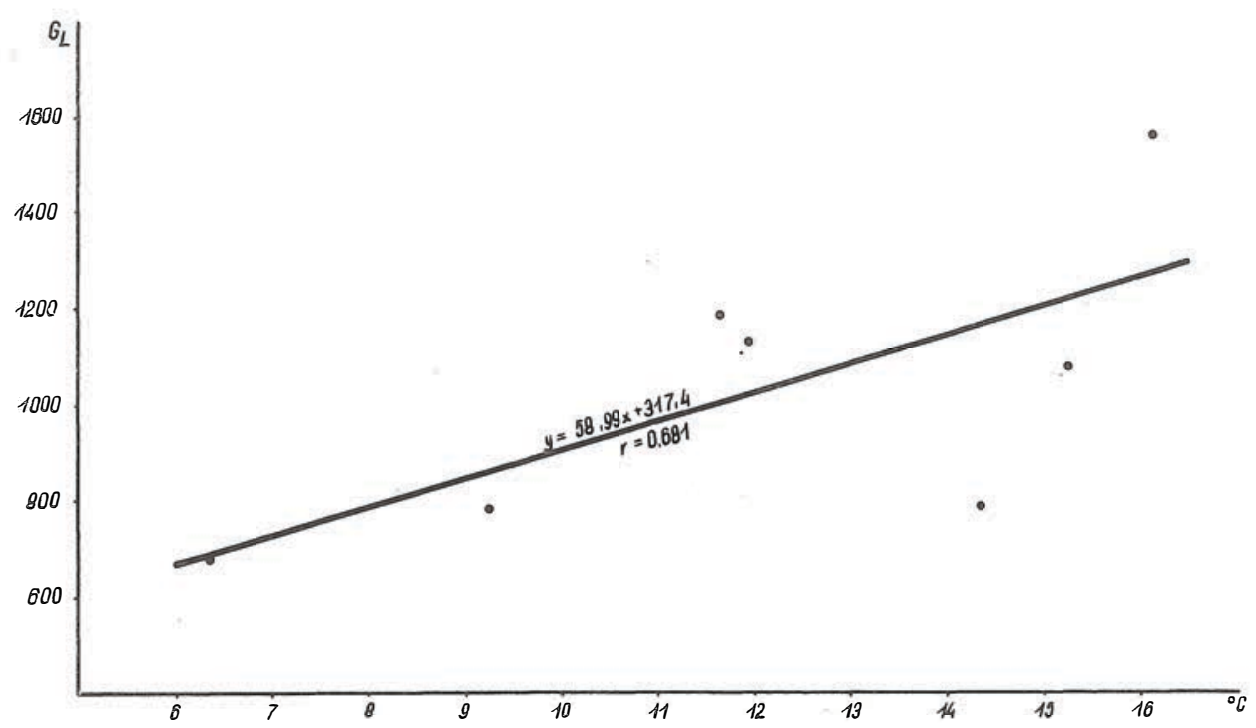

Fig. 7. Relationship between cod length growth coefficient and water temperature in the ICNAF area

Results of testing the effects of salinity on growth of various fish species are summarised in Table 3. As seen from the table, in all five cases examined the correlation coefficients were positive, indicating a direct relationship between salinity and the length growth coefficient. The values of the slope coefficient express in this case an average change in the length growth coefficient accompanying a $1 \%$ change in salinity. Fig. 8 presents the length growth coefficient-bottom water salinity relationship for the Southern Baltic flounder (Cięglewicz et al., 1969); as seen from the figure, the correlation is direct and has a rather high coefficient $(r=0.770)$.

Population density is a factor exerting a certain influence on fish growth. However, an accurate determination of the effect of population density on requires a possibly precise determination of the population abundance, which is most often a rather complicated 
Table 3

Relationship between length growth coefficient $\left(\mathrm{G}_{\mathrm{L}}\right)$ and salinity $(\%)$ in various fish species

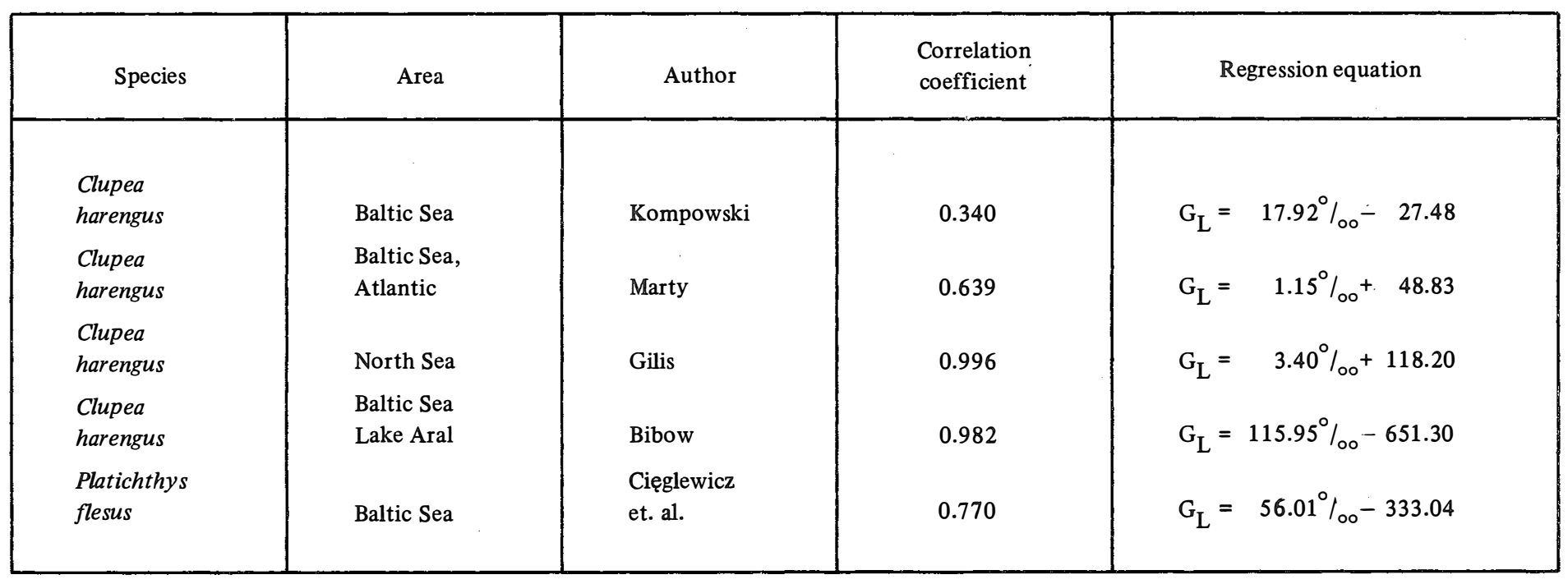




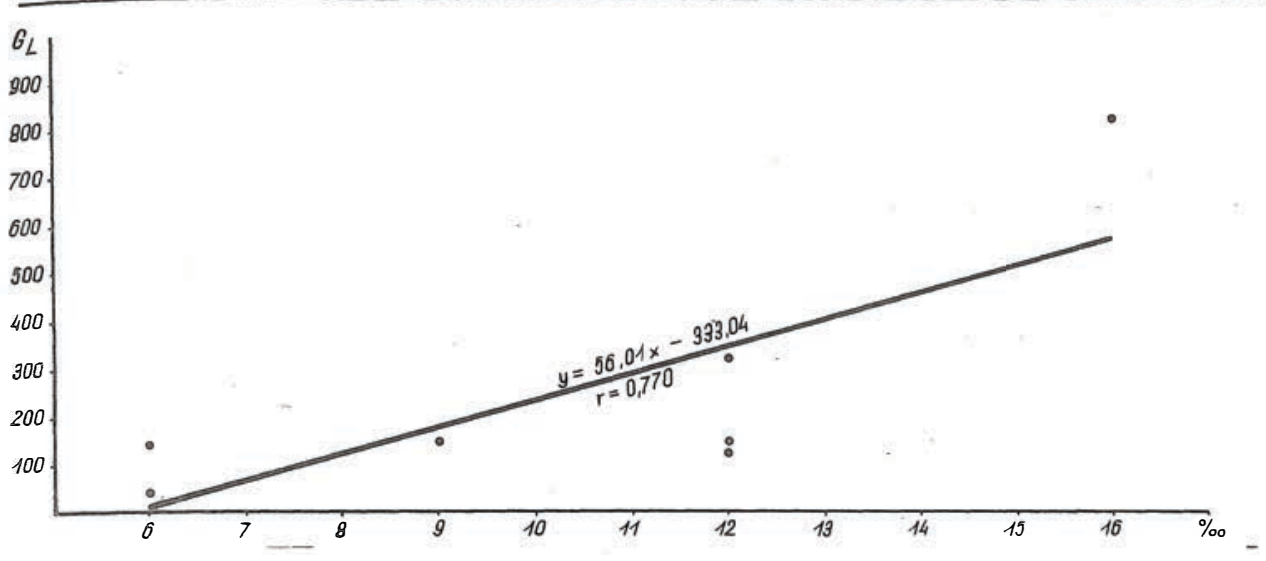

Fig. 8. Relationship between flounder length growth coefficient and bottom water salinity in the Southern Baltic

task. Changes in the population abundance are usually inferred from, for instance, changes in catches, the latter - when converted to units fishing effort - constituting a fairly reliable indicator of abundance.

Relationships between the length growth coefficients of various species and their population densities, summarised in Table 4, were calculated from changes of those indirect indices of population abundance. These relationships cannot be regarded as unequivocally corresponding, since the authors contributing data for the calculations used different methods of assessing changes in population densities. Cushing (1961) and Sonina (1965) took units fishing effort in account to express the changes in carches, whereas the remaining workers referred to the changes in catch absolute magnitude only.

Regardless of the criticisms listed above, the results in Table 4 indicate to a reverse relationship to exist between the length growth coefficient and population density (all the correlation coefficients proved negative). Fig. 9 provides an example of such a correlation for the North Sea sardine (Cushing, 1961), the population density being

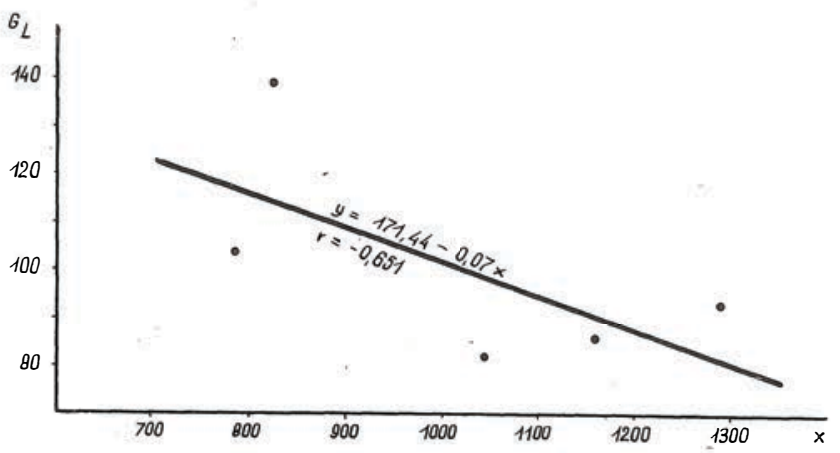

Fig. 9. Relationship between sardine length growth coefficient and population density in the North Sea ( $\mathrm{x}=$ catch in cwt per unit fishing effort) 
Table 4

Relationship between length growth coefficient $\left(G_{L}\right)$ and population density $(x)$ in various fish species

\begin{tabular}{|c|c|c|c|c|}
\hline Species & Area & Author & $\begin{array}{c}\text { Correlation } \\
\text { coefficient }\end{array}$ & Regression equation \\
\hline $\begin{array}{l}\text { Clupea } \\
\text { harengus } \\
\text { Clupea } \\
\text { harengus } \\
\text { Clupea } \\
\text { harengus } \\
\text { Sardina } \\
\text { pilchardus } \\
\text { Melanogrammus } \\
\text { aeglefinus } \\
\text { Platessa } \\
\text { platessa }\end{array}$ & $\begin{array}{l}\text { North Sea } \\
\text { Sea of Japan } \\
\text { North Sea } \\
\text { North Sea }\end{array}$ & $\begin{array}{l}\text { Gilis } \\
\text { Motoda } \\
\text { Parrish, Craig } \\
\text { Cushing } \\
\text { Sonina } \\
\text { Jensen }\end{array}$ & $\begin{array}{l}-0.397 \\
-0.895 \\
-0.475 \\
-0.651 \\
-0.588 \\
-0.849\end{array}$ & $\begin{aligned} G_{L} & =214.78-0.002 x \\
G_{L} & =277.17-0.960 x \\
G_{L} & =157.60-0.610 x \\
G_{L} & =171.44-0.070 x \\
G_{L} & =1906.31-568.190 x \\
G_{L} & =131.46-0.005 x\end{aligned}$ \\
\hline
\end{tabular}


expressed indirectly as catch (in cwt) per unit fishing effort. As seen from the figure, a decline in the magnitude of relative catch was accompanied by an increase in the sardine length growth coefficient, and vice versa.

When comparing growth of conspecific individuals caught over a period of several years, the length growth can be almost always found to accelerate with time. To find a growth rate acceleration in fishes caught over consecutive years of the period analysed, it is sufficient in most cases to compare lengths attained by the studied individuals at a certain age over several years. The well-pronounced phenomenon of this kind was found to occur in various fish species. However, it is particularly conspicuous when growth of fishes caught in the consecutive years is compared by analysing changes in their length growth coefficients, and when the period considered covers more than 10 years.

Results of the correlations calculated for the length growth coefficients of fishes and the year of their capture are summarised in Table 5. Noteworthy are high values of the correlation coefficient indicating the significance of the correlations. The coefficients were positive in all 12 cases studied. Fig. 10 presents the length growth coefficients for the North Sea herring (calculated from data reported by Burd, 1962) as related to the year of capture. The growth coefficient of herring is observed to increase with time, the correlation coefficient being high $(r=0.911)$. In case of the relationships presented in Table 5, the regression equation slope coefficient expresses a change in the length growth coefficient accompanying a 1-year difference in time.

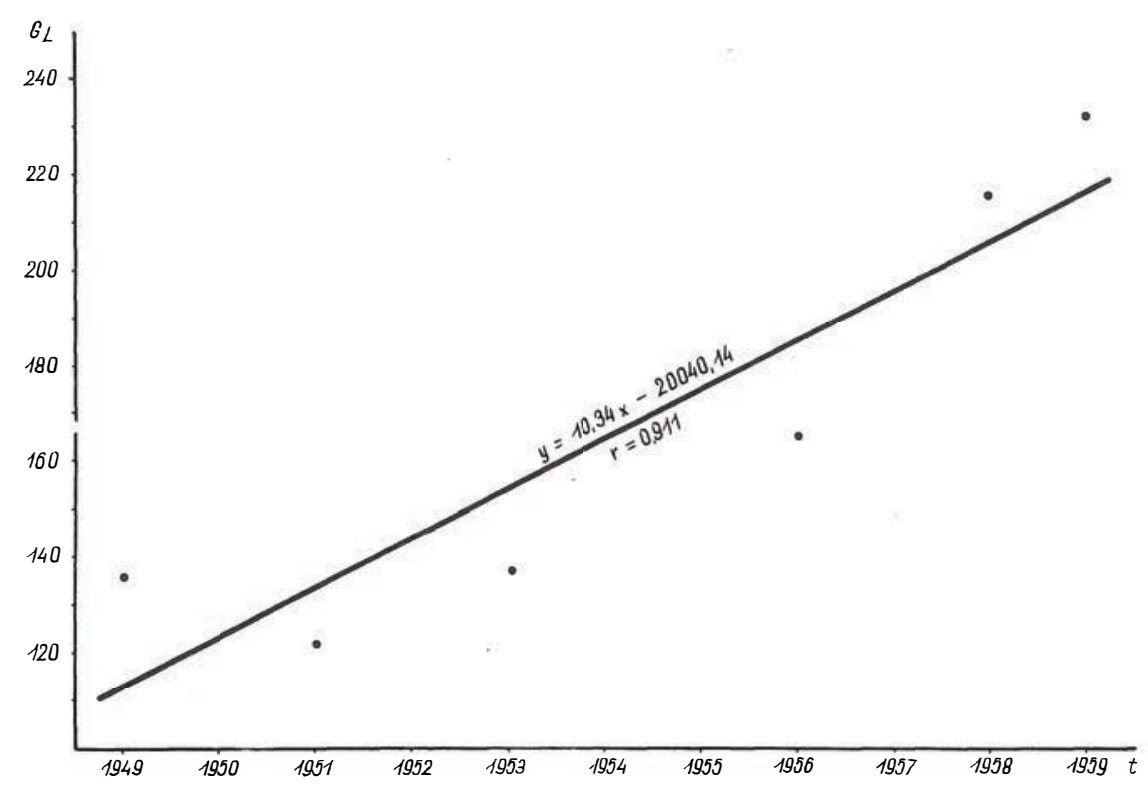

Fig. 10. Relationship between herring length growth coefficient and year of capture in the North Sea $(t=$ year of capture $)$ 
able 5

Relationship between length growth coefficient $\left(G_{L}\right)$ and year of capture $(t)$ in various fish species

\begin{tabular}{|c|c|c|c|c|c|c|c|}
\hline Species & Area & Time period & Author & $\begin{array}{l}\text { Correlation } \\
\text { coefficient }\end{array}$ & \multicolumn{3}{|c|}{ Regresion equation } \\
\hline $\begin{array}{l}\text { Clupea } \\
\text { harengus }\end{array}$ & North Sea & $1931-1960$ & Gilis & 0.809 & $\mathrm{G}_{\mathrm{L}}=$ & $1,83 \mathrm{t}-$ & 3388.81 \\
\hline $\begin{array}{l}\text { Clupea } \\
\text { harengus }\end{array}$ & North Sea & $1952-1960$ & Cushing & 0.910 & $\mathrm{G}_{\mathrm{L}}=$ & $5.49 t-$ & 10583.24 \\
\hline $\begin{array}{l}\text { Clupea } \\
\text { harengus }\end{array}$ & Sea of Japan & $1920-1943$ & Motoda & 0.879 & $\mathrm{G}_{\mathrm{L}}=$ & $1.01 \mathrm{t}-$ & 1695.33 \\
\hline $\begin{array}{l}\text { Clupea } \\
\text { harengus }\end{array}$ & Norwegian Sea & $1963-1966$ & $\begin{array}{l}\text { Benko, } \\
\text { Bakanev }\end{array}$ & 0.622 & $\mathrm{G}_{\mathrm{L}}=$ & $25.71 \mathrm{t}-$ & 50096.29 \\
\hline $\begin{array}{l}\text { Clupea } \\
\text { harengus }\end{array}$ & North Sea & $1951-1955$ & Parrish, Craig & 0.964 & $\mathrm{G}_{\mathrm{L}}=$ & $3.60 t-$ & 6886.30 \\
\hline $\begin{array}{l}\text { Clupea } \\
\text { harengus }\end{array}$ & Barents Sea & $1953-1956$ & Seliwestrowa & 0.796 & $\mathrm{G}_{\mathrm{L}}=$ & $21.82 t-$ & 42549.94 \\
\hline $\begin{array}{l}\text { Clupea } \\
\text { harengus }\end{array}$ & North Sea & 1949-1959 & Burd & 0.911 & $\mathrm{G}_{\mathrm{L}}=$ & $10.34 t-$ & 20040.14 \\
\hline $\begin{array}{l}\text { Sardina } \\
\text { pilchardus }\end{array}$ & Nort Sea & $1949-1954$ & Cushing & 0.740 & $\mathrm{G}_{\mathrm{L}}=$ & $3.81 \mathrm{t}-$ & 7351.59 \\
\hline $\begin{array}{l}\text { Pollachius } \\
\text { virens }\end{array}$ & Nort Sea & $1968-1970$ & Gołubiatnikowa & 0.960 & $\mathrm{G}_{\mathrm{L}}=$ & $917.92 \mathrm{t}-$ & 5742695.85 \\
\hline $\begin{array}{l}\text { Melanogrammus } \\
\text { aeglefinus }\end{array}$ & Barents Sea & $1950-1963$ & Sonina & 0.748 & $\mathrm{G}_{\mathrm{L}}=$ & $89.03 t-$ & 173338.00 \\
\hline $\begin{array}{l}\text { Trisopterus } \\
\text { esmarkii }\end{array}$ & North Sea & $1959-1963$ & Raitt & 0.530 & $\mathrm{G}_{\mathrm{L}}=$ & $2.45 \mathrm{t}-$ & 4738.34 \\
\hline $\begin{array}{l}\text { Platichthys } \\
\text { flesus }\end{array}$ & Gulf of Gdańsk & $1954-1958$ & Cięglewicz & 0.425 & $\mathrm{G}_{\mathrm{L}} \dot{z}$ & $75.27 \mathrm{t}-$ & 146196.29 \\
\hline
\end{tabular}




\section{DISCUSSION}

The correlation coefficients and regression equations, contained in Tables 1-5, describing effects of various environmental factors on growth of the species studied should be treated only as an approximated picture of the relationships analysed. Under natural conditions, a given population is influenced simultaneously by all the factors, whilst in the above presentation each factor was isolated and described independently of the rest. Therefore some correlation coefficients are low as if indicating the lack of any significant correlation. However, a more plausible explanation of the situation observed is that many factors exert their influence at the same time, thus obliterating the true picture of the influence of any single factor.

A through anylsis of patterns formed by points in Figs. 6-10 expressing effects of varying action of the respective environmental factors on the length growth coefficient may cast some doubts as to whether a linear correlation represents correctly all the relationships studied. The arrangement of points in, for example, Figs. 6, 8, and 10 would suggest a curvilinear relationship to be most appropriate, in which case, however, the relationships wxpressed by linear and curvilinear correlations are not comparable. Moreover, it was not the objective of the present paper to describe in depth the effect of various factors on fish growth, but to test if the growth coefficients calculated in the proposed way are suitable to serve this purpose. The linear correlation used in all cases allows additionally the regression equation slope coefficient to be used in assessing the magnitude of a given factors's effect on fish growth.

Inasmuch as the results on the effects of latitude, temperature, salinity, and population density on fish growth, used in the present paper, confirm the other authors' results obtained with different methods, the data in Table 5 on changes in growth of species caught from an area over several years are of a particular interest. In all 12 cases studied, the length growth coefficient of a species was found to increase from year to year, which resulted mainly from an accelerated growth rate. A similar phenomenon will be found in most exploited species if only the data on their growth over an appropriately long time period are available. This clear and common course of growth changes indicates a permanent action of a factor accelerating growth of the exploited fish species. Among the others, an excessive commercial exploitation of fish populations, leading to a considerable decrease in the populations' abundance and, consequently, to their growth acceleration is suggested to be the responsible factor.

\section{CONCLUSIONS}

The procedure of describing fish length and weight growth, presented in this paper, and the preliminary results obtained, when compared to the mathematical models of growth used so far, bring some new elements into focus. The possibility of determining the limiting (maximum) growth time, $t_{\max }$, impossible to calculate from the asymptotic 
growth models, may be mentioned in this context. The limiting growth time enables, in turn, to describe the growth of a species by means of growth coefficients involving two principal characteristics of growth: its rate and duration. Values of growth coefficients may be used to compare growth of various species and to test the nature of environmental factors' effects on the growth process itself.

The following conclusions can be drawn from the results presented:

1. A binomial was to describe the fish length growth, while the growth of weight was assessed by means of a trinomial. The polynomial parameters were calculated from the empirical data using the least squares method.

2. The application of polynomials to the mathematical description of fish growth allows to determine the limiting (maximum) growth time, $\mathrm{t}_{\max }$. The results obtained when using polynomials are equally accurate as those derived from the most frequently used von Bertalanffy model.

3. The length and weight growth coefficients $\left(\mathrm{G}_{\mathrm{L}}\right.$ and $\mathrm{G}_{\mathrm{W}}$, respectively) are the principal indices with which to descibe fish growth when using polynomials. The coefficients represent the areas contained between the growth curve, x-axis (time-axis), and a line perpendicular to the latter and intersecting it at $t_{\max }$. The higher the rate, and the longer the duration of growth of a species, the higher are the growth coefficients.

4. The length growth coefficient $\left(G_{L}\right)$ can serve to estimate effects of environmental factors on growth of different species. If a linear correlation is applied to express the relationship between a given factor and a length growth coefficient, the regression equation slope coefficient may be assumed to represent the magnitude of the effect of the factor in question.

5. When growth of conspecific individuals caught commercially over a period of several years from the same area is compared by means of their length growth coefficients, an increase in the coefficient's values from year to year is almost always observed. The phenomenon is presumabbly associated with an increasing overfishing observed in most species.

\section{REFERENCES}

Beverton R.J.Ho, Holt S.J., 1957: On the dynamics of exploited fish populations. - Fishery Invest., Ser. II, XIX, London.

Burd A.C., 1958: Calanus and the Herring. - ICES C.M. 1958, Herring Committee, No 36.

Burd A.C., 1962: Growth and Mortality in the Bank Stock. - ICES C.M. 1962, Herring Committee, No 128.

Cięglewicz W., Draganik B., 1969: Charakterystyka wzrostu czarniaka (Pollachius virens L.) z Morza Norweskiego i Morza Północnego. [Characteristic of growth of coalfish (Pollachius virens L.) from the Norwegian Sea and the North Sea]. - Prace MIR, 15, ser. A.: 133-152.

Cięglewicz W., Draganik B., Żukowski C., 1969: Charakterystyka wzrostu storni (Platich thys flesus L.) i skarpia (Scophthalmus maximus L.) za pomocą równania von Bertalanffy'ego. [Characteristic of growth of flounder (Platichthys flesus L.) and turbot (Scophthalmus maximus L.) by means of the v. Bertalanffy's equation]. - Prace MIR, ser. A: 121-132. 
Cięglewicz W., Hoppe G., 1970: The relation between th.e water temperature and the rate of growth of flounder (Platichthys flesus L。) in Gdańsk Bay. - Zesz. nauk. AR Szczecin - Acta Ichth. et Pisc. I: 67-72.

Collective Report, 1949: Promyslovyje ryby SSSR. Piscepromizdat, Moskwa.

Cushing D.H., 1961: Progress report of North Herring Working Group. -- ICES C.M. 1961, Herring Committee, No 10.

May A.W., Pinhorn A.T.9 Wells $\mathbb{R}_{\circ}$, Fleming A.M., 1964: Cod growth and temperature in the Newfoundland Area. - IXNAF spec. publ., No 6: 545-555.

Rounsefell G.A., Everhart W.H., 1953: Fishery Science, its Methods and Applications. New York-London.

Sonina M.A., 1965: Relationship between the growth rate and population density of haddock in the Barents Sea. - ICNAF spec. publ., No 6: 565-570.

Szypula Jo, 1977: Zastosowanie wielomianów 2 i 3 stopnia do charakterystyki wzrostu ryb. [Application of second and third order polynomials to fish growth description]. AR Szczecin, Rozprawy, nr 52.

Taylor C.C., 1958: Cod growth and temperature. - Journ. du Cons., XXIII, No 3: 366-370.

Translated: mgr Teresa Radziejewska

\section{OKREŚLENIE WPEYWU CZYNNIKÓW ŚRODOWISKOWYCH NA WZROST RYB PRZY POMOCY WSPÓICZYNNIKA WZR OSTU, OBLICZANEGO NA PODSTAWIE MA TEMATYCZNEJ CHARAKTERYSTYKI WZROSTU RYB PRZY UZ̊YCIU FUNKCJI WIELOMIANOWYCH}

\section{Streszczenie}

W pracy przedstawiono metodę matematycznej charakterystyki wzrostu ryb przy pomocy nieasymptotycznych modeli wzrostu. Wzrost długości określano wielomianem 2, zaś wzrost ciężaru wielomianem 3 stopnia. Parametry wielomianów obliczano metodą najmniejszych kwadratów na podstawie danych empirycznych.

Zastosowanie funkcji wielomianowych pozwoliło na określenie teoretycznego maksymalnego czasu wzrostu $\left(\mathrm{t}_{\max }\right)$, co $\mathrm{z}$ kolei umożliwiło obliczanie współczynnika wzrostu, jako powierzchni zawartej pomiędzy krzywą wzrostu, osią odciętych (osią czasu) oraz prostopadłą do tej osi, przechodzącą przez punkt $t_{\max }$. Wartości współczynników wzrostu obliczano przez cał kowanie równań wzrostu $\mathrm{w}$ granicach od 0 do $t_{\max }$.

Wyniki uzyskane przy zastosowaniu funkcji wielomianowych były równie dokładne, jak otrzymane przy użyciu stosowanego najpowszechniej matematycznego modelu wzrostu - równania von Bertalanffy'ego.

Stwierdzono, że współczynnik wzrostu długości $\left(\mathrm{G}_{\mathrm{L}}\right)$ może być zastosowany do określania wpływu takich czynników jak szerokość geograficzna, temperatura, zasolenie oraz zagęszczenie populacji na wzrost ryb, drogą obliczania korelacji między zmianami wartości współczynnika wzrostu oraz zmianami nasilenia oddziaływania omawianych czynników. Współczynnik kierunkowy w równaniach regresji, określających charakter poszczególnych zależności, może być traktowany jako miernik siły działania danego czynnika na wzrost ryb. 
Е紫 Шипула

ОПРЕДЕЛЕНИЕ ВЛИЯНИЯ ЭЛЕМЕНТОВ СРЕДЫ НА РОСТ РЫБ

ПРИ ПОМОЩИ КОЭФФИЦИЕНТА РОСТА, РАСЧИТАННОГО НА ОСНОВЕ МАТЕМАТИЧЕСКОЙ ХАРАКТЕРИСТИКИ РОСТА РЫБ, С ИСПОЛЬЗОВАНИЕМ МНОГОЧЛЕННЫХ ФУНКЦИЙ

\section{Резюме}

В работе представлен метод математической характеристики роста рыб при помощи неасимптотических моделей роста. Увеличение длины определяли многочленом 2-ой степени, увеличение веса многочленом 3-ей степени. Коэффициенты многочленов определяли на основе эмпирических данных по методу найменьших квадратов.

Применение многочленных Функций дало возможность определить теоретическое максимальное время роста $\left(t_{\max }\right)$, благодаря чему стало возможным расчитывать коэффициент роста как площадь содержащуюся между кривой роста, осей абсцис (осей времени) и перпендикуляром к этой оси проходящим через точку $t_{\text {max }}$ Значения коэффициентов роста определяли путем интегрирования уравнений роста в пределах от 0 до $t_{\max }{ }^{*}$

Результаты, полученные на основе многочленных функций, сходны с результатами полученными при исспользовани общепринятой математической модели роста - уравнения von Bertalanffy .

Установлено, что коэффициент увеличения длины $\left(G_{L}\right)$ может применяться для определения влияния на рост рыб таких элементов как: географическая широта, температура, соленость, уплотнение популяции, путем расчетов кореляции между изменениями значений коэффициента роста, а изменениями интенсивности воздействий отмеченных элементов. Угловой коэффициент в уравнениях регресии, определяющих характер изменения отдельных зависимостей, может служить измерителем силы воздействия данного элемента на рост рыб.

Перевод: др Станислав Дудно

Adress:

Received: 4 X 1979 r.

Doc. dr hab. Jerzy Szypuła

Insty tut Ichtiologii AR

71-550 Szczecin, ul. Kazimierza Królewicza 4

Polska - Poland 